\title{
Tradução
}

Translation

\section{É verdade que estamos vivendo uma Crise da Verdade? ${ }^{1}$}

\author{
STEVEN SHAPIN \\ Universidade Harvard | EUA \\ Tradução e apresentação \\ ROGÉRIO MONTEIRO \\ Universidade de São Paulo | USP
}

\section{Apresentação da tradução para o público brasileiro: à guisa de um registro historiográfico}

A crítica das ciências está em crise. Pudera. Nas últimas décadas, ela se esforçou para desenvolver e amolar ferramentas que pudessem colocar em outros termos o legado dos paradigmas de Thomas Kuhn. Para ela, as afirmações científicas não eram entidades bem-resolvidas, estáveis por um período longo de bonança, de ciência normal, até que uma revolução viesse em seu encalço e colocasse tudo em novos termos. A verdade científica, depois da virada antropológica na sociologia e na história das ciências, nos anos 1970, passou a ser explicada como um equilíbrio delicado de acordos cavalheirescos, de poder, de interesses, embrulhado em caixas-pretas vistosas que, em seu interior, no entanto, mantêm uma rede confusa de agentes humanos e não-humanos, instrumentos e teorias mal-acabadas. Se o discurso científico - ao invés da verdade, para honrar os pós-pós - podia ser descrito dessa maneira, qual lugar deveríamos dar às invenções e descobertas dos cientistas? Um espaço largo se abriu para questionar o poderio da empresa científica de tal modo que um analista mais liberal, como Paul Feyerabend, em 1987, chegou a sugerir, em seu Contra o método, que a ciência deveria ser "ensinada como uma concepção entre muitas outras e não como 0 único caminho para a verdade e a realidade". "Tudo o que digo é que não-especialistas frequentemente sabem mais do que os especialistas e deveriam, portanto, ser consultados, e que profetas da verdade (incluindo os que empregam argumentos) em geral são impelidos por uma visão que conflita com os próprios eventos que, supõe-se, essa visão estaria explorando", acrescentou ele em uma nova edição de 1992.? 
Quem acompanhou as redes sociais nos últimos dois anos sabe bem que está cada vez mais difícil seguir Feyerabend sem que se escreva longos senões a essa espécie de crítica. Figuras importantes da política, aqui e acolá, começaram a usar as suas tribunas para questionar as ciências e os cientistas de maneira tão virulenta que toda a comunidade universitária - cientistas e críticos da ciência- se viu nas cordas, e precisou ajustar seus projetos intelectuais. 0 risco era de que conquistas civilizacionais importantes, advindas das ciências, entrassem em extinção, e com elas a natureza e a humanidade. Em 2004, Latour já se mostrava preocupado com o andar da carruagem: "deveríamos estar em guerra também, nós os acadêmicos, os intelectuais? Será realmente nosso dever adicionar mais ruínas às ruínas? Será realmente tarefa das humanidades adicionar desconstrução à destruição? Mais iconoclastia à iconoclastia? 0 que aconteceu com o espírito crítico? Perdeu a força?"

Em dezembro de 2019, Steven Shapin publicou um interessante ensaio na Los Angeles Review of Books sobre 0 tema. 0 texto circulou por aqui em algumas plataformas digitais. Na época, parecia caber como uma luva para pensar as ciências, os cientistas e o sistema universitário brasileiros que tentava fazer frente às diatribes inconsequentes do bolsonarismo e de seus ministros. Shapin parecia percorrer uma linha tênue entre continuar com o projeto da crítica às ciências e envidar uma defesa da prática científica. Em outras palavras: mal comparando o contexto americano e brasileiro, colocava a dificuldade de se fazer crítica às ciências em um momento de extrema fragilidade e risco das ciências. "Parece irresponsável ou perverso rejeitar a ideia que existe sim uma Crise da Verdade. Não temos tempo para comentários delicados; o que precisamos é de um ataque frontal aos Negacionistas da Verdade", diz Shapin sobre as ciências nos Estados Unidos, no texto traduzido.

Entre nós, a questão acabou virando tema renitente de conversas. E alguns colegas da SBHC resolveram organizar a mesa "Anticientificismo e negacionismos no Brasil e no mundo" dentro do $17^{\circ}$ Seminário Nacional de História da Ciência, em novembro de 2020, com referências a vários autores, mas também a este texto de Shapin.

Quando o li, em dezembro de 2019, pareceu-me um texto intelectualmente corajoso e instigante. Não para ter seus argumentos copiados, mas para fazer pensar uma agenda local de pesquisa, para apresentar aos alunos - no meu caso, alunos de história das ciências, de ética na pesquisa e de estudos culturais - que tentam a todo o tempo conciliar o problema das hierarquias, do poder e dos interesses na ciência com suas vantagens civilizacionais, seja lá o que chamamos civilização.

Rapidamente escrevi, em janeiro de 2020, aos editores da Los Angeles Review of Books, pedindo autorização para fazer uma tradução do texto. 0 editor da revista, Boris Dralyuk, gentilmente autorizou e me encaminhou para a editora da área de ciências, Michele Pridmore-Brown, que me respondeu: "Steven Shapin diz estar de acordo em dar a permissão [para a publicação da tradução]. Ele pede que eu transmita os seus melhores votos a vocês e diz que a hospitalidade que recebeu [no Brasil], anos atrás, foi memorável". Ele se referia à sua visita a São Paulo, em 2012, quando abriu 0 $13^{\circ}$ Seminário Nacional de História da Ciência e da Tecnologia, em São Paulo, com a conferência de título provocativo: "Ouem é o cientista?" A visão de um historiador sobre como o papel do cientista desenvolveu-se no tempo, qual é ele agora e porque respostas à questão da identidade do cientista são pertinentes para questões práticas sobre autoridade e credibilidade das ciências. Pelo título da conferência, à época, já se via que o estatuto do cientista estava em questão. Mas ainda eram tempos de bonança. Não aventávamos o tamanho da onda que agora tentamos compreender.

Agradeço aos editores e a Shapin por autorizarem a tradução, e, aos colegas Márcia Regina Barros da Silva e Thomás Haddad, que leram as primeiras versões do texto em português e apontaram problemas e possíveis soluções.

\section{Tradução}

É claro que está ocorrendo uma Crise da Verdade e é claro que nós vivemos em uma sociedade da "Pós-Verdade". Evidências dessa crise estão em todo lugar, extensivamente noticiadas na mídia não-Fake-News, aquela que é lida 
pelos Bem-Pensantes [Right-Thinking people]. A Casa Branca faz circular "fatos alternativos" e o advogado pessoal do presidente explica que "a verdade não é verdade". Trump nega que a culpa das mudanças climáticas seja dos humanos. Os ativistas antivacinas proliferam como um vírus. Estes são Grandes e Importantes exemplos da Negação da Verdade - muita coisa acontece quando se põe em dúvida a Veracidade das afirmações dos especialistas sobre mudanças climáticas e segurança das vacinas. Mas há muitas formas inofensivas de Negação da Verdade que também são epidêmicas. Astrologia e homeopatia crescem nas sociedades ocidentais modernas, e um terço dos jovens americanos pensa que a Terra pode ser plana. Ao mesmo tempo, os Defensores da Verdade apontam o dedo acusatório para os culpados, com Trump, Heidegger, Latour, Derrida e Quentin Tarantino inacreditavelmente compartilhando a cama do relativismo pecaminoso. $\underline{5}$

Eu mencionei alguns exemplos que consideram a crise da credibilidade como um indicador da Crise da Verdade. Embora em boa parte deste texto eu lide com as questões da ciência, vale a pena notar que muitas áreas do conhecimento, como o jornalismo, a medicina, a economia e as finanças, têm sua credibilidade questionada, assim como várias instâncias de governo, e assim por diante. Na verdade, foi Michael Gove, um parlamentar britânico conservador, ministro responsável pelas universidades, quem anunciou um pouco antes do referendo de 2016 em favor do Brexit que "as pessoas deste país estão fartas dos especialistas". Enquanto ele tentava se retratar da afirmação, a resposta dada pela Grã-Bretanha do Brexit ao seu desabafo mostrou fartamente que ele havia acertado em um ponto nevrálgico.

Parece irresponsável ou perverso rejeitar a ideia de que existe sim uma Crise da Verdade. Não temos tempo para comentários delicados; 0 que precisamos é de um ataque frontal aos Negacionistas da Verdade [Truth Deniers]. Mas é sempre bom nos assegurarmos da natureza do problema antes de tentar resolvê-lo. Conceber o problema como uma Crise da Verdade, ou mesmo como uma Crise da Autoridade Científica, não é a meu ver o melhor ponto de partida. Não há razão para complacência, mas há razão para reavaliar quais partes de nossa cultura estão em estado crítico e, uma vez identificadas com precisão, quais terapias estão disponíveis para tratá-las.

Comecemos com a ideia de Verdade. 0 que poderia ser mais importante, especialmente se a palavra é usada como usualmente tem sido nos textos acadêmicos - como uma substituta para Realidade? Mas há uma espécie de brilho luminoso ao redor da noção de Verdade que prejulga e preprocessa as atitudes apropriadas a adotar diante dela. A Verdade segue incólume. Deus é a Verdade. E a Verdade vos libertará. Quem, exceto um maluco ou malévolo, poderia ser contra a Verdade? Afinal, foi Pôncio Pilatos que perguntou, "0 que é a verdade?", e então se retirou para lavar as mãos.

Assim, aqui vai uma sugestão aparentemente pedante sobre como conceituar a Verdade e sobre por que nosso atual problema pode não ser uma Crise da Verdade. No uso moderno cotidiano, Verdade é um termo notavelmente incomum. 0 lugar natural da Verdade não é na fala cotidiana, mas nas cenas em que a linguagem está de folga, quase partindo em férias. A noção de Verdade costuma brotar quando afirmações sobre "o que importa" [what's the case] são colocadas sob pressão, escrutinadas, ou escolhidas para celebrações. Afirmações sobre "o que importa" podem então se tornar exemplos da Verdade, rodeada por uma aura epistêmica. A Verdade é invocada quando juramos dizê-la - "somente a verdade, nada mais que a verdade" - em contextos jurídicos, ou ao preencher formulários oficiais, quando somos advertidos a não mentir; ou naqueles exames escolares e burocráticos em que temos de escolher entre o Verdadeiro e o Falso. A Verdade entra no jogo quando se suspeita que alguma coisa importante foi deliberadamente escondida - como quando Al Gore, em resposta ao descrédito nas mudanças climáticas, insistiu em "uma verdade inconveniente", ou, quando exigimos que nos digam a Verdade sobre a segurança dos organismos geneticamente modificados. $\underline{6}$

Conversas sobre Verdade aparecem naquelas ocasiões especiais, como discursos de formatura, quando cientistas dizem que a vocação deles é a Busca da Verdade. E vale a pena considerar aqui a diferença entre dizer isso e dizer que estão trabalhando para sequenciar um gene do câncer de mama, ou para prever quando certo vulcão indonésio está próximo da erupção. A Verdade está para as Coisas-que-Importam [Matters-That-Are-the-Case] mais ou menos como encantamentos, provérbios e aforismos estão para a fala cotidiana. A Verdade está mais associada a algumas práticas intelectuais formais do que a outras - à filosofia, religião, arte, e, claro, ciência, embora na ciência ela tenha uma aparente especificidade. Basta compararmos aquelas ciências que parecem se ajustar mais à noção de Busca 
da Verdade àquelas que se ajustam menos: física teórica versus sismologia, as ciências cognitivas versus pesquisas sobre o melhor sabor para um novo refrigerante. E, claro, a Verdade circula nas aulas e periódicos de filosofia, onde as teorias sobre o que ela é são apresentadas, defendidas e exaustivamente disputadas. Coletivamente, os filósofos sabem que a Verdade é muito importante, mas eles não sabem coletivamente o que ela é.

Eu disse que a Verdade aparece nas preocupações sobre os problemas do conhecimento com os quais supostamente estamos aflitos, quando, ao dizer que temos uma Crise da Verdade, intensificamos o problema e lhe damos uma carga moral. Em maio de 2019, Angela Merkel proferiu uma aula inaugural em Harvard. Bastante atenta ao significado do lema de Harvard, Veritas, a chanceler alemã descreveu as condições para a investigação acadêmica que, disse ela, exige que "nós não descrevamos mentiras como verdade e a verdade como mentiras", nem que "aceitemos abusos [Misstände] como uma coisa normal". A plateia de Harvard a aplaudiu de pé: eles entenderam a referência política codificada a Trump e evidentemente concordaram que o oposto da Verdade seria a mentira - entendida como uma afirmação que não só não corresponde à realidade, mas que é um engodo intencional. Podemos, no entanto, achar que o oposto da Verdade é alguma coisa sem sentido, um erro, ou uma simples bobagem, mas chamá-lo de mentira é deslocar a Verdade para o campo da moral. Merkel não estava dando a Harvard uma lição sobre filosofia, mas sobre virtudes cívicas globais.

Nós não estamos experimentando, eu gostaria de sugerir, uma Crise da Verdade ou mesmo uma Crise da Autoridade Científica. Os problemas que estamos confrontando são reais, mas bastante específicos. Façamos uma retrospectiva sobre os problemas apresentados no início. Perguntei a muitas pessoas nos últimos meses sobre a Crise da Verdade. Elas pareciam entender o que eu queria dizer e concordavam que essa crise existe sim. Mas, quando eu pedia exemplos, praticamente todos mencionavam os mesmos casos - a negação da mudança climática, o sentimento antivacina, e várias formas de pensamento antievolucionista. Não se nega a importância desses exemplos. Há consequências materiais que resultam da crença ou da descrença na mudança climática antropogênica ou na segurança das vacinas, mas, embora seja deprimente que atitudes antievolucionistas sejam tão amplamente difundidas, não está claro que muita coisa de importância prática - para além do que é ensinado nas escolas - aconteça por causa do ceticismo em relação ao darwinismo.

Esses exemplos não constituem um lista muito longa a partir da qual possamos dar como certa a Crise da Verdade, pelo menos nos domínios relativos à autoridade científica - certamente não é longa o suficiente para justificar a conclusão de que o sentimento anticientífico é pervasivo e profundo. Consideremos, também, o status dos itens da lista. Existe sim uma ampla e deplorável rejeição à segurança das vacinas, à mudança climática e à mudança das espécies. Notemos, no entanto, quão longa é a lista de fatos científicos e teorias sobre os quais não há disputa e que desfrutam de um grau de aceitação que é de causar inveja a muitas outras práticas culturais. Aqui, é importante fazer uma distinção entre as afirmações da ciência especializada que são objeto de alguma preocupação pública e aquelas que são objeto de indiferença.

Grandes parcelas do público têm encontrado e, sem fricção ou frisson, aceitado uma imensa quantidade de afirmações científicas - fatos e inferências a partir de fatos. ${ }^{?}$ Elas incluem praticamente tudo do currículo científico escolar e, menos importante, algumas coisas que têm aparecido na cada vez mais fragmentada mídia de massa - por exemplo, as leis do movimento e da termodinâmica; a velocidade da luz e a natureza do impulso nervoso; a natureza físsil de um isótopo de urânio. É evidente que o conhecimento público sobre fatos como estes é superficial, inseguro, ou (se quisermos) deficiente, mas o que se deve levar em conta nesses casos é a exposição pública $e$ a falta de qualquer disputa significativa. Assim, comparando à lista de itens sob disputa que constituem a porção científica da Crise da Verdade, nós temos uma lista bem longa de coisas que não estão sob disputa, muitas delas circulando tranquilamente na cultura pública.

São muitos os comentários a fazer sobre essa questão. 0 primeiro diz respeito à "ignorância científica", ou, como se tem falado nos estudos acadêmicos de Ciência, Tecnologia e Sociedade, "a (in)compreensão pública da ciência". Existe sim uma enorme ignorância pública das teorias e dos fatos científicos; o conhecimento público do conheci- 
mento científico consensual está qualquer coisa entre o pobre e o terrível. Como é de costume, os Bem-Pensantes [Right-Thinking People] balançarão suas cabeças tristemente, suspirarão, e condenarão tais posturas. Atualmente, a ignorância científica é normalmente apontada como a causa da Crise da Verdade ou a principal evidência de que tal crise existe. Segue daí o remédio: a ignorância pública precisa ser reparada. 0 público deveria ser exposto a muito mais ciência - os fatos e as teorias científicos de várias disciplinas, ou, se não houver espaço suficiente no currículo escolar, então certamente uma versão qualquer poderia ser escolhida entre as várias, e frequentemente incompatíveis, versões do Método Científico. Quando isso acontecer, o público irá pensar corretamente sobre as mudanças climáticas e a segurança das vacinas.

Na formulação famosa de Carl Sagan, “Nós vivemos em uma sociedade extremamente dependente da ciência e da tecnologia, na qual muito poucos sabem qualquer coisa sobre ciência e tecnologia". Mas a ignorância pública da ciência é compreensível. Não é algo ruim; chega a ser, em muitos aspectos, um estado de coisas altamente desejável. Claro, queremos futuros cientistas - estou usando essa palavra em um sentido amplo - para conhecer os fatos, teorias e procedimentos relevantes das suas especialidades. E, na medida em que o conhecimento científico é considerado parte do que se pode entender como uma "pessoa educada" - a despeito das discordâncias atuais entre os educadores sobre 0 que isto significa e se "pessoas educadas" ainda devam ser o produto das universidades -, isto também poderia justificar as pinceladas científicas na escola e na educação superior.

Ainda assim, a educação científica de grande parte do público não envolvido com atividades técnicas é, pode-se dizer, naturalmente limitada. Queremos que os fatos, teorias e métodos da produção do conhecimento científico sejam opacos da mesma maneira e pelas mesmas razões que queremos que os mecanismos internos dos nossos carros ou celulares sejam opacos. Não queremos abrir as caixas pretas desses objetos; queremos que eles funcionem; e, com exceção daquelas pessoas que realmente gostam de saber dessas coisas, podemos não querer ficar sobrecarregados com os princípios de funcionamento do carro ou do celular. Se quisermos debater essas minhas conclusões sobre a ignorância científica como virtude prática, consideremos o leque completo de conhecimentos científicos do tipo caixa-preta que poderíamos querer abrir, explorar, e fazer com que todos os tipos de pessoa necessariamente dominassem. Esse leque inclui a ciência encapsulada em artefatos como carros e telefones, mas também ideias caixas-pretas e aquelas das quais alguém já está cuidando [black-boxed and taken-care-of ideas] - as leis de movimento, termodinâmica, aerostática etc. Se alguém quiser dizer que o público precisa de conhecimento fundamental, que permita que as pessoas lidem com questões científicas candentes, então talvez essa pessoa possa explicar - para os educadores e estudantes - exatamente como o conhecimento, digamos, das leis do movimento ou da termodinâmica encoraja as pessoas a tomarem decisões melhores sobre as mudanças climáticas. Não é fácil.

Aqueles que oferecem Mais Ciência no currículo e na mídia como solução para a Crise da Verdade tendem a igualar ciência com a ciência acabada, a ciência dos livros didáticos, os fatos científicos seguros e as teorias bem estabelecidas. Um público mais bem educado nessas coisas será, presume-se, mais capaz de separar a ciência confiável do lixo, da pseudociência, dos erros e das mentiras. Mas vamos lembrar da pequena lista de conhecimento erroneamente questionado que, a rigor, constitui de fato a tal Crise da Verdade científica. A evolução pela seleção natural é questionada em parte porque ela se opõe a artigos caros da fé de tipo fundamentalista; a segurança das vacinas é questionada em parte porque pais estão desesperadamente engajados em evitar o risco à saúde dos seus filhos; as mudanças climáticas causadas por humanos são questionadas em parte porque, se de fato acontecem, as pessoas podem ter que andar de bicicleta, comer menos carne, e levar suas sacolas reutilizáveis para fazer compras. Colocando em termos mais claros: a ciência questionada é aquela que parece valer a pena disputar. No século XVII, Thomas Hobbes observou, e explicou, uma diferença crucial entre geometria e ética - as deliberações éticas são endemicamente sujeitas a disputas, enquanto as da geometria quase nunca:

A doutrina do Certo e Errado é perpetuamente disputada pela Pluma e pela Espada: enquanto a doutrina das Linhas e Figuras não é; porque os homens não se importam, nesse assunto, com o que é verdade, sendo uma coisa que não interfere em nenhuma ambição, lucro ou luxúria de homem algum. Pois eu não 
duvido que se ela fosse contrária a qualquer direito de controle de um homem qualquer, ou ao interesse dos homens que têm controle, Que três Ângulos de um Triângulo devem ser iguais a dois Ângulos de um Quadrado, tal doutrina teria sido não só disputada, como suprimida pela queima de todos os livros de Geometria, no limite da capacidade daquele a quem interessar pudesse..$\underline{-}$

As questões de interesse, assim, são quase sempre questões de contenda. A ciência dos livros didáticos é uma ciência fechada, não lida com as questões de interesse, e um notável indicador de tal fechamento - momentâneo senão permanente - é que esse conhecimento "não interfere em nenhuma ambição, lucro ou luxúria" humanos.9

0 problema com que estamos lidando é mais bem descrito não como falta de ciência na cultura pública, mas como excesso. Dados os absurdos e erros que se empilham a nosso redor, pode parecer loucura dizer isto, mas a questão merece ser explorada um pouco mais. Consideremos, novamente, os negacionistas das mudanças climáticas, os antivacinas, e os criacionistas. Eles estão evidentemente equivocados, mas, como os negacionistas do pouso da lua e os terraplanistas, sua rejeição ao Bem-Pensar [Right-Thinking] não se apresenta como anticiência. Ao contrário, ela vem toda paramentada com os supostos fatos, teorias, métodos sancionados e posturas de objetividade e desinteresse associados à ciência genuína. Os teimosos costumam anunciar sua completa adesão aos valores científicos oficialmente estimados - ceticismo, desinteresse, universalismo, a distinção entre fatos consolidados e teorias provisórias - e frequentemente o fazem de maneira muito mais rigorosa do que a ciência que rejeitam. A noção de ciência dos negacionistas algumas vezes parecem ser, de certa maneira, hipercientífica, mais realista que o rei. E, se quisermos exemplos de tendências hipercientíficas nas assim chamadas pseudociências, existem atualmente estudos refinados da assim chamada astronomia bíblica, uma mania instigada nos anos 1950 pelo psiquiatra Immanuel Velikovsky, ou podemos considerar a atenção metodológica meticulosa da parapsicologia, ou podemos nos perguntar por que os estudantes das ciências humanas são inundados com lições sobre 0 Método Científico enquanto químicos e geólogos estão normalmente satisfeitos em dominar apenas os vários métodos de suas especialidades. Os Negacionistas da Verdade descobrem fatos científicos e teorias vergonhosamente ignorados pelas elites; eles defendem concepções de um Método Científico coerente, estável e efetivo que dizem que essas elites violam; eles insistem na necessidade do ceticismo científico radical, da replicação universal, e da abertura a visões alternativas, tudo em oposição às elites. Dessa perspectiva, quem é realmente anticientífico? Quem são os verdadeiros Negacionistas da Verdade? $?^{10}$

Quem acompanha as afirmações dos Negacionistas da Verdade não pode deixar de reconhecer este excesso de ciência - tantos fatos e teorias desconhecidos nas universidades de elite, tanta abundância de artigos científicos e instituições, um coro cacofônico de vozes científicas. Este é um mundo em que a "essência" democrática da ciência é levada bastante a sério e a aristocracia e o elitismo condenados. Por que instituições como Oxford, Harvard, e outras similares monopolizam a Verdade científica? É difícil condenar esse princípio de democracia científica, mas, como uma prática normal, ele é condenado todo o tempo. É difícil e, agora, também imprudente dizer, mas a ciência estabelecida, como todas as outras práticas especializadas e profissionais, tem controlado o acesso, as condutas adequadas, e os direitos a falar e julgar. Nesse sentido, ela não é democrática. E é este direito a falar e julgar em ciência que agora está sendo vigorosamente contestado. Ou, para colocar de maneira mais dura, há muita ciência por aí - e, de maneira clara, isto é parte do nosso problema.

Apertemos uma vez mais o parafuso epistêmico e os modernos Defensores da Verdade forçarão os Negacionistas a enfrentar o fato - tão frequentemente mal compreendido - do consenso científico. Os Negacionistas afirmam falsamente que conseguem flagrar os pontos de divergência na ciência, e assim argumentam que não existe base sólida para seguir os passos práticos que os especialistas demandam - por exemplo, no caso das ciências das mudanças climáticas, descarbonizar nossas fábricas, casas, fazendas, carros e dietas. Insistir no fato de que há um consenso pode ser convincente em determinados contextos, mas em muitos outros pode chutar o balde ladeira abaixo: um público do qual se espera que saiba distinguir ciência real de má ciência (ou de não-ciência) agora é chamado a discriminar entre supostos especialistas que dizem que há consenso científico, e supostos especialistas que dizem que não há, ou que afirmam tal consenso é evidência de uma conspiração do Estado profundo.11 
Existe um apelo visceral e um argumento atualmente poderoso contra o que eu estou defendendo aqui, contra a ideia de que a ignorância científica não descreve adequadamente nossos problemas presentes. Tal argumento é Donald Trump - sua confiança na teoria da mudança climática como maquinação chinesa; sua desconsideração grosseira da especialização científica em favor de malucos, ressentidos e criminosos. Trump não conhece nenhuma ciência, e o planeta paga o preço. Trump é um imbecil, um mentiroso em escala industrial. Comparemos Trump com Obama e as políticas ambientais de sua administração: boa ciência; melhores - mesmo que não boas o suficiente - políticas. Mas segue aqui uma outra afirmação, provavelmente irritante: não está claro que Trump conheça menos ciência do que Obama - um homem muito inteligente embora, não obstante, seja apenas um advogado formado em Harvard. E não há razões para acreditar que o conhecimento científico pessoal dos políticos faça muita diferença nas realidades políticas concretas.

Mais do que isso, uma diferença entre os dois - e uma consideração pertinente às conexões entre Verdade especializada e consequências políticas - não é saber ciência, mas saber onde a ciência está: quem deve ser reconhecido como bem informado e confiável; em quem acreditar; quais instituições considerar como lugar do conhecimento genuíno. Conhecer esse tipo de coisa - chamemos isto de um tipo de conhecimento social - é diferente de conhecer as leis dos movimentos, a composição em nucleotídeos do DNA, ou as ferramentas estatísticas para determinar a temperatura global e estimar sua taxa de mudança. Esse tipo de conhecimento envolve conhecer corretamente a reputação científica das instituições; conhecer corretamente a integridade daqueles que testificam por essas reputações; conhecer corretamente as virtudes e os vícios das instituições e seus procedimentos; e até mesmo conhecer corretamente as características pessoais e os interesses materiais dos porta-vozes dessas instituições e daqueles que testificam pelas suas qualidades. Isto envolve saber quais opiniões levar em consideração, e levar a sério, sobre assuntos que ignoramos. Esse tipo de conhecimento não é técnico, e as pessoas podem dizer até que não é científico, ou mesmo que ele não é de fato conhecimento - mas quase todo o conhecimento técnico que temos é adquirido nessas bases. Em um passado distante, eu trabalhei com ciência avançada (em genética), mas - e eu falo aqui somente por mim - tudo 0 que eu sei sobre mudanças climáticas, incluindo o fato de que Trump está errado, é uma cortesia desse conhecimento social. Ser uma pessoa bem informada pode significar saber um monte de coisas, mas certamente significa saber quem sabe e quem não sabe..$^{12}$

Dada a composição demográfica do mundo acadêmico, é possível que praticamente todos que leem este ensaio possuam esse tipo de conhecimento e lancem mão dele em seus julgamentos. Assim, pode-se pensar que este conhecimento social é fácil de obter e não requer nenhuma expertise especial. Devemos reconhecer que não existe um curso dedicado a ensinar como adquirir tal conhecimento, mas não é fácil obtê-lo e quase impossível explicá-lo efetivamente para aqueles que já não o possuem. Pessoas com esse tipo de conhecimento parecem ser pessoas como nós, possuidoras de senso comum e julgamento razoável, compartilhando de nossas reservas de autoevidências, suas mentes competentemente abastecidas de ferramentas culturais dedicadas. Saber quais são as melhores fontes da Verdade é o mesmo que ser um certo tipo de pessoa. E é por isso que é tão difícil entender como deve ser alguém que acredita no contrário - por exemplo, alguém que acredita que a vacina tríplice viral apresenta um risco inaceitável. Mas como colocar no papel e comunicar efetivamente o conhecimento que se adquire dessa forma? Como justificar isto na cultura pública? Acredite nos climatologistas de Harvard e não acredite em seus pares na Universidade Batista do Leste do Kentucky ou na Exxon Mobil. Prefira o New York Times ao Breitbart News. Essas recomendações não parecem muito aceitáveis. Elas são francamente não democráticas e estimulam o preconceito. É improvável que queiramos esses conselhos distribuídos como normas globais - mas este é o problema com a aparência e com a exigência de normas globais racional e moralmente justificadas.

Talvez agora fique claro o quão difícil é para o leigo reconhecer a Verdade quando ela está bem na frente dele. E por que expor o público a mais ciência provavelmente não curará a Crise. Para conhecer a Verdade, para ter a crença certa, as pessoas precisam, essencialmente, ser muito mais parecidas com a gente - a questão não é saber fatos e teorias como patrimônio pessoal (a maioria de nós também não sabe), mas confiar nas pessoas e instituições em que nós confiamos. A Crise da Verdade é mais bem descrita como uma Crise do Conhecimento Social e, mais especificamente, como uma Crise das Instituições - da autoridade e legitimidade institucionais. 
Eu me concentrei aqui na Crise da Verdade reconhecida em relação à ciência, mas existem muitas instituições contemporâneas que parecem experimentar uma crise de autoridade na transmissão do seu tipo específico de conhecimento. Não seria correto igualar declínio com colapso da autoridade das instituições especializadas: há evidências de que esta autoridade permanece considerável. Levantamentos das atitudes públicas para com a ciência e as instituições públicas produziram resultados ambíguos dependendo de como as questões foram escritas, do que conta como evidência, e onde e quando as pesquisas foram conduzidas. Alguns levantamentos de opinião indicam que a confiança na ciência tem caído bastante entre grupos conservadores nos Estados Unidos enquanto permanece notavelmente estável em outros grupos sociais, enquanto outros estudos não oferecem nenhuma evidência de que há qualquer mudança radical em curso na confiança pública na ciência em geral. ${ }^{13}$ Outros levantamentos dão pouco sustento à ideia do declínio, indicando (para o Reino Unido e a União Europeia) "atitudes públicas amplamente positivas em relação dos especialistas - contrariando a opinião sombria associada à chamada 'era da pós-verdade'". 14 0 sociólogo Gil Eyal inicia seu ótimo recente livro sobre os dilemas modernos da autoridade especializada concordando aparentemente que "nós estamos no meio de um completo assalto à especialização", mas em seguida qualifica a afirmação: "Nem toda a 'ciência' está sob assalto";

O que é preciso explicar não é a "morte da especialização", "desconfiança nos especialistas" ou o "assalto à ciência" unilaterais, mas o pushmi-pullyu ${ }^{1 \underline{15}}$ de duas cabeças formado por uma dependência sem precedentes na ciência e na especialização, acoplada a suspeita, ceticismo e rejeição crescentes das descobertas científicas, da opinião dos especialistas, ou mesmo de áreas inteiras de investigação. $\frac{16}{6}$

Ainda assim, os problemas de credibilidade e legitimidade relacionados a instituições culturais não são novos. Jamais precisamos de análises críticas para sustentar a convicção de que os governos mentem. Maquiavel recomendou a falsidade como boa política, e, em uma famosa formulação do século XVII, o diplomata inglês Henry Wotton definiu um embaixador como um "cavalheiro honesto enviado ao exterior para mentir pelo bem do seu próprio país". Os juízes da Alta Corte inglesa, ao deliberarem sobre uma petição que demandava que intimassem Boris Johnson por evidentes falsidades no referendo sobre a saída do Reino Unido da Comunidade Europeia, julgaram contra os peticionários, dizendo que todo mundo sabe que mentir faz parte da política. Trump mente de hora em hora, e o trumpismo é com frequência considerado uma versão extrema da norma global emergente. Sabemos que políticos mentem: a questão agora é saber se estão mentindo mais, ou mais descaradamente, do que costumavam fazer. E não é preciso dizer que empresas mentem para proteger seus lucros corporativos e o bônus para seus executivos. Assim, uma coisa que pode ser dita sobre a ciência é que suas esparsas dificuldades como fonte reconhecida da Verdade começaram a se assemelhar aos problemas muito mais profundos de autoridade intelectual comumente associados aos pronunciamentos de governo e empresas.

Se a Crise é de instituições e da credibilidade de seu conhecimento, como a instituição da ciência chegou a este ponto? As atuais dificuldades de legitimidade institucional decorrem do sucesso institucional - no caso da ciência, do sucesso histórico em enfronhar investigações e descobertas científicas na vida civil moderna, especialmente nas práticas de governo e comércio. Podemos considerar isto como a realização do sonho baconiano - inserir o conhecimento científico na constituição e no exercício do poder, e garantir um amplo reconhecimento de que é a ciência que cumpre esse papel. É claro que devemos entender o quanto as ciências naturais e as matemáticas práticas já têm sido desdobradas em governamentalidade e comércio desde a antiguidade arquimediana e vitruviana. Na Alemanha de Bismark e do imperador Guilherme, as inovadoras indústrias químicas, farmacêuticas e elétricas absorveram um grande número de pesquisadores academicamente treinados, como também fizeram os grandes laboratórios de pesquisa industrial que emergiram nos Estados Unidos por volta do começo do século XX. E foi nesse período que a aliança assimétrica entre ciência, Estado e indústria era entusiasticamente celebrada, e cada vez mais cientistas profissionais eram empregados pela indústria e pelos laboratórios governamentais do que pelas instituições de educação superior. Em 1917, Max Weber descreveu a ocupação [Beruf] científica apenas em termos do desinteresse, mas a realidade era que a função científica estava sendo executada mais, e mais perceptivelmente, nas instituições de poder e produção. $\frac{17}{}$ 
Foi, no entanto, o sucesso do Projeto Manhattan que gestou uma duradoura confederação na Guerra Fria entre ciência, militares, especialistas civis e administradores governamentais. As universidades, consideradas como o "lar natural" da ciência, foram fundamentalmente alteradas pela aliança entre poder e conhecimento. Em 1961, o presidente Eisenhower falava do complexo industrial-militar, e, em 1968, um senador corretamente modificou a expressão para o complexo militar-industrial-acadêmico. Esta foi uma situação que há muito vinha sendo defendida pelos líderes da comunidade científica, e com a qual a grande maioria dos cientistas estavam satisfeitos, mesmo se, por volta da metade do século XX - particularmente entre os Criadores da Bomba -, alguns poucos começassem a ter remorsos nostálgicos. A vida científica se tornou normalizada em instituições há muito consideradas como externas à ciência, mas também se tornou internamente normalizada, e foi amplamente reconhecida como tal em alguns setores da cultura pública. Por um lado, a normalização profissional do emprego científico significou certo grau de autonomia (como sociólogos de meados do século XX reconheceram), mas também significou certo grau de conformismo e conservadorismo (como Thomas Kuhn observou nos anos 1960).

Conforme essas sensibilidades sobre a natureza da vida científica foram chegando na cultura pública, elas pavimentaram um caminho para disputar afirmações científicas - não porque tais afirmações fossem um idioma técnico colocado a serviço de objetivos comerciais ou políticos supostamente externos, mas porque elas poderiam ser caminhos interesseiros para atingir objetivos profissionais. Isto ficou evidente, por exemplo, na controvérsia de 2009-2010 que ficou conhecida como "Clima-gate": uma "conspiração" de climatologistas foi acusada de manipular dados para proteger as apostas de carreira que eles haviam feito pela validade do aquecimento global. A vantagem material assegurada pela alegada prevaricação das ciências do clima não foi, digamos, em benefício de companhias de turbina de vento dinamarquesas, mas de interesses de carreira dos próprios cientistas. Quanto mais acreditássemos na origem humana das mudanças climáticas, dizia o rumor, mais as carreiras desses climatologistas iriam se justificando. E se os Defensores da Verdade insistirem que ainda assim existe um consenso científico sobre as mudanças climáticas, os negacionistas dirão, "Agora sabemos o que este 'consenso' realmente significa. 0 que significa é: está tudo dominado por vocês". 18 Por consenso, leia-se conspiração.

Assim, em meados do século XX, a comunidade acadêmica - nos Estados Unidos e em muitos outros países ocidentais - alcançou um objetivo muito desejado por muitos dos seus membros mais ativos: ela estava emaranhada no tecido da vida social, econômica e política cotidianas. Para muitos estudiosos acadêmicos da ciência - historiadores, sociólogos, e, acima de tudo, filósofos - a parcela da ciência que não fosse exclusivamente acadêmica restaram muito pouco visíveis, mas a realidade era que a maior parte da ciência estava agora conduzida dentro dos escritórios de governo e de negócios, e muito da aprovação pública da ciência estava baseado no sentido das suas utilidades externas - se, de fato, poder e lucro podem ser vistos como objetivos externos ao trabalho científico. ${ }^{19}$ Além disso, na medida em que a academia pode ainda ser vista como o lugar natural da ciência, as universidades começam também a reformular suas marcas como um tio normal de instituição civil. Há pelo menos meio século, as universidades têm insistido que elas não deveriam ser pensadas como torres de marfim; elas não só não deixaram de se envolver com preocupações sociais como se engajaram na promoção de soluções. $\underline{20}$ Elas passaram a falar cada vez menos sobre Verdade e cada vez mais sobre Crescimento da Economia e 0 aumento do poder aquisitivo de seus egressos. A cultura da auditoria impôs os padrões do mercado neoliberal à avaliação da investigação acadêmica, oferecendo um sinal adicional de que a ciência pertence ao mercado, guia-se pelas preocupações do mercado e é avaliada pelos seus critérios. 0 envolvimento da ciência com os negócios e a administração pública historicamente acompanhou a separação da ciência das instituições religiosas. Isto, também, foi celebrado pelos porta-vozes científicos como uma grande vitória, mas a diferença é que, em séculos passados, a ciência e a religião estavam ambas no Negócio da Verdade.11

Quando a ciência se torna tão extensivamente amalgamada com o poder e o lucro, suas condições de credibilidade acabam se tornando cada vez mais parecidas com as instituições com as quais ela se confunde. Seus problemas são os problemas delas. Os negócios não lidam com os negócios da Verdade; negócios são negócios. Assim, por que deveríamos esperar que a ciência mergulhada nos negócios tenha direitos naturais sobre a noção de Verdade??22 A mesma questão se aplica à ciência mergulhada no exercício de poder estatal. 0 conhecimento fala por meio de instituições; 
ele é mergulhado nas práticas cotidianas da vida social; mas se as instituições e as práticas cotidianas estão com problemas, também estará o conhecimento. Dada a relação entre a ordem do conhecimento e a ordem da sociedade, não é surpresa que a outra Grande Coisa que hoje se crê amplamente estar em Crise seja a democracia liberal. $\underline{23}$ A questão hobbesiana Cui bono? (Quem sai ganhando?) normalmente é pensada como pertinente às práticas políticas e de comércio, então por que não deveria haver disputas sobre os vereditos científicos oriundos, e vistos como tais, do governo, dos negócios, e das instituições que anunciam estar ligadas a esses vereditos?

Se uma crise da autoridade científica supostamente confirma um fracasso cultural, então esse fracasso decorre significativamente do sucesso institucional: a normalização da ciência. Não sendo mais serva do Sagrado, a ciência pode até ter vencido uma batalha pela supremacia cultural, mas a um preço: 0 abandono do monopólio tradicional da Verdade pelo Sagrado. A filosofia da ciência preferida entre cientistas e aqueles que apoiam e elogiam seu trabalho agora é uma certa versão do pragmatismo. A Verdade Transcendental foi eclipsada. Entre aqueles que seguem as modas teóricas, a Verdade é identificada com o Poder - substantivamente, e não como um simples teste de validade baconiano. Nesse contexto, falar em desinteresse não faz sentido algum. É aqui que os teóricos culturais da moda pronunciam automaticamente o nome de Michel Foucault. Foucault descreveu como, por volta do fim da Segunda Guerra Mundial, o "universal" foi substituído pelo "intelectual específico" - tomando Oppenheimer como paradigma, cujo aparecimento foi associado com a concessão da especialização técnica ao "Estado ou Capital". Foi neste contexto que Foucault anunciou a coabitação da Verdade e do Poder:

O importante aqui, creio, é que a verdade não é alguma coisa fora do poder ou que não tem poder: ao contrário do mito cuja história e funções demandam maiores estudos, a verdade não é o prêmio dos espíritos livres, a filha da solidão prolongada, nem o privilégio daqueles que conseguiram se libertar. A verdade é uma coisa mundana: ela é produzida somente em virtude de múltiplas formas de coação. E ela induz efeitos regulares de poder. ?4 $^{4}$

Se existe um declínio na confiança nas afirmações científicas - e a realidade e a extensão de tal declínio permanecem problemáticas -, ele acompanha o declínio no desinteresse percebido. E o declínio no desinteresse pode ser o preço pago pelo sucesso mundano. Boa parte do atual estrago na autoridade cientifica - tal como ele é - deriva das considerações que estão além do controle dos cientistas, mas outra parte tem sido uma ferida autoinfligida pela própria comunidade.

Seria romanticamente nostálgico e praticamente impossível separar a ciência do comércio e dos governos e retorná-la a uma Utopia de Marfim. Um retorno nostálgico à Verdade e ao desinteresse significam uma ciência muito menor e mais pobre, e isto significaria renunciar a muitos dos benefícios, que nós gozamos, decorrentes do emaranhamento da ciência no tecido da vida civil cotidiana. Assim, como resolver a Crise tal qual a estamos experimentando? Francamente, eu não acho que exista uma solução disponível, e eu procurei argumentar por que algumas das soluções propostas, hoje bastante conhecidas, podem se revelar ineficazes. Mas, apesar disso, muitos problemas que não têm solução podem e devem ser administrados, e da melhor maneira possível de modo a dar tempo e espaço para que as soluções finalmente surjam. Se a minha explicação é substancialmente correta, então os cientistas e aqueles que se importam com eles deveriam apreciar mais o preço pago pelo sucesso civil e se abrir mais às sugestões sobre como aquele emaranhamento poderia ser administrado. Um provérbio inglês diz que aquele que janta com o diabo precisa de uma longa colher: instituições civis não são o diabo, mas suas demandas, de maneira geral, não se casam com a dedicação à Verdade. E tal apreciação poderia também encorajar alguns cientistas a falar menos para o público sobre como a ciência aumenta os lucros e aumenta o poder e mais na linguagem da dedicação e da vocação, se a memória dessas práticas ainda sobrevive em algum lugar. 


\section{Notas e referências bibliográficas}

1 Texto original em inglês: SHAPIN, Steven. Is There a Crisis of Truth? Los Angeles Review of Books, December 2, 2019. Disponível em: https://lareviewofbooks. org/article/is-there-a-crisis-of-truth/. Acesso: 04 de Fevereiro de 2021. Tradução e apresentação de Rogério Monteiro (USP).

2 FEYERABEND, Paul K. Contra o método. São Paulo: Editora UNESP, 1989. pp. 9 e 17.

3 LATOUR, Bruno. Por que a crítica perdeu a força? De questões de fato a questões de interesse. 0 que nos faz pensar, v. 29, n. 46, p. 173-204, 2020.

4 A mesa foi coordenada por Dominichi Miranda de Sá, da Casa de Oswaldo Cruz/Fiocruz. Teve a participação dos colegas Gabriel da Costa Ávila, da Universidade Federal do Recôncavo da Bahia, Simone Kropf, da Casa de Oswaldo Cruz/Fiocruz, e de Fernando Nicolazzi, UFRGS. Kropf, aliás, fez várias referências ao texto de Shapin ao longo da sua fala.

5 KAKUTANI, Michiko. The Death of Truth: Notes on Falsehood in the Age of Trump. New York: Tim Duggan Books, p. 48, 2018. MCINTYRE, Lee. Post-Truth. Cambridge: MIT Press, 2018.

6 Uma exceção evidente são declarações como "é verdade" ou "na verdade" nas conversas cotidianas, embora a "verdade" aqui funcione mais como um gesto cívico, uma muleta linguística, não um julgamento de veracidade ou qualquer coisa correspondente. Na verdade, eu escrevi um livro chamado "Uma história social da verdade" (SHAPIN, S. A Social History of Truth. Chicago: University of Chicago Press, 1994). 0 título foi em parte provocativo e o seu conteúdo lida com questões epistêmicas mais modestas - fatos observacionais e experimentais e inferências a partir deles sobre questões teóricas.

7 Discuto esta questão brevemente em: SHAPIN, S. Science and the Modern World. In: SHAPIN, S. Never Pure: Historical Studies of Science as if It Was Made by People with Bodies, Situated in Space, Time, and Society, and Struggling for Credibility and Authority. Baltimore: The Johns Hopkins University Press, p. 377-391, p. 383-385, 2010. [N.T: 0 texto possui tradução em português. SHAPIN, S. Nunca Pura: Estudos Histórico de Ciência como se Fora Produzida por Pessoas com Corpos, Situadas no Tempo, no Espaço, na Cultura e na Sociedade e Quem Se Empenham por Credibilidade e Autoridade. Minas Gerais: Ed. Fino Traço, 2013]. 0 argumento foi poderosamente elaborado em: EYAL, Gil. The Crisis of Expertise. Cambridge: Polity, p. 7, 2019.

8 HOBBES, Thomas. Leviathan, ed. C. B. Macpherson. London: Penguin, 1968; orig. publ. 1651, p. 166.

9 Cf. LATOUR, Bruno. Why Has Critique Run Out of Steam? From Matters of Fact to Matters of Concern. Critical Inquiry, v. 30, p. 225-248, 2014. Meu uso é mais rústico, e mais diretamente hobesiano, do que 0 de Latour. Mobilizo as questões de interesse [matters of concern] para discernir as afirmações que têm consequência para "a ambição, o lucro e a luxúria" das pessoas. Tal sentido parece, no entanto, compartilhar das sensibilidades que Latour usou (p. 237) quando ele fala da "fusão das questões de fato com questões de interesse altamente complexas, historicamente situadas e ricamente diversas. Pode-se fazer um tipo de coisa com canecas, jarras, pedras, cisnes, gatos, tapetes, mas não com a sincronização elétrica dos relógios do escritório de patentes de Einstein em Berna. Coisas agregadas não podem ser jogadas contra você como objetos". [N.T: Texto também traduzido ao português. Ver: LATOUR, op. cit., 2020. Essa tradução precisou ser ligeiramente adaptada aqui para fazer frente ao comentário de Shapin sobre as questões de fato e de interesse.] Os sociólogos Harry Collins e Trevor Pinch têm repetidamente falado da importância de se ter um espaço nos currículos para a ciência em construção [science-in-the-making], por exemplo, em: COLLINS, Harry M. PINCH, Trevor. The golem: What you should know about science. Cambridge: Cambridge University Press, 1998, 2ed.

10 Sobre a ideia de hiperciência, ver: GORDIN, Michael. The Pseudoscience Wars: Immanuel Velikovsky and the Birth of the Modern Fringe. Chicago: University of Chicago Press, 2012; e a minha apreciação: SHAPIN, Steven. Catastrophism. London Review of Books, v. 34, n. 21, November 8, p. 35-38, 2012. Sobre parapsicologia, ver, por exemplo, COLLINS, Harry M.; PINCH, Trevor. The Construction of the Paranormal: Nothing Unscientific is Happening. The Sociological Review Monograph, n. 27, p. 237-269, 1979. Para pensar a fetichização da metodologia nas ciências sociais: ARONOWITZ, Stanley; AUSCH, Robert, A Critique of Methodological Reason. The Sociological Quarterly, v. 41, p. 699-719, 2000.

11 ORESKES, Naomi. The Scientific Consensus on Climate Change. Science, 306, no. 5702, p. 1686, 2004; ORESKES, Naomi; CONWAY, Erik M., Merchants of Doubt: How a Handful of Scientists Obscured the Truth on Issues from Tobacco Smoke to Global Warming. New York: Bloomsbury, 2010. 0 panorama feito por Oreskes sobre "o consenso criticamente alcançado" por uma comunidade científica livre e socialmente diversa como garantia para uma "confiança informada" foi detalhado em suas recentes Conferências Tanner: ORESKES, Naomi. Why Trust Science? Princeton: Princeton University Press, 2019. 0 reconhecimento da diversidade, da criticidade aberta, do desinteresse pertinente, do uso de métodos apropriados, do conhecimento superior, podem muito bem ser argumentos localmente poderosos em favor da confiança. No entanto, persiste o problema da descrição das circunstâncias em que 0 público reconhece que comunidades de especialistas específicas de fato possuem tais características. Oreskes parece admitir o problema, resolvendo-o ao dizer que "os marcadores sociais da especialização são evidentes aos não especialistas" (pp. 221-222). Há, porém, que se comentar que nem a existência desses "marcadores" nem o seu valor diagnóstico são autoevidentes para o público.

12 Este argumento foi rascunhado em: SHAPIN, S. Science and the Modern World, op. cit., 2010, p. 386-389. É possível, é claro, que os negam as mudanças climáticas como Trump ou os executivos das companhias de petróleo possuam o mesmo tipo de conhecimento social de seus oponentes, que eles acreditem nas deliberações dos consensos de especialistas, mas prefiram publicamente vender deturpações. A diferença aqui seria que outras agendas informam suas alegações, por exemplo, assegurar lucros de curto prazo ou apelas à sua base política - ou pode ser que eles simplesmente não liguem para o destino do planeta.

13 GAUCHAT, Gordon. Politicization of Science in the Public Sphere: A Study of Public Trust in the United States, 1974 to 2010. American Sociological Review, 77, pp. 167-187, 2012; FUNK, Cary. Mixed Messages about Public Trust in Science. Issues in Science and Technology, v, 34, n. 1, p. 86-88, 2017; FUNK, Cary; JOHNSON, Courtney; HEFFERON, Meg. 5 key findings about public trust in scientists in the U.S. Publicado em 05 de Agosto de 2019. Disponível em: https://www.pewresearch.org/fact-tank/2019/08/05/5-key-findings-about-public-trust-in-scientists-in-the-u-s/

14 DOMMETT, Katharine; PEARCE, Warren. What Do We Know about Public Attitudes towards Experts? Reviewing Survey Data in the United Kingdom and European Union. Public Understanding of Science, v. 28, p. 669-678, 2019.

15 [N.T]: Uma referência à Ihama de duas cabeças que aparece na série de livros infantis Dr. Dolittle, de Hugh Lofting. Cada cabeça puxa 0 animal - ou 0 empurra - para um lado diferente.

16 EYAL, op. cit., 2019, p. 3-4; Veja também: FUNK, Cary; HEFFERON, Meg; KENNEDY, Brian; JOHNSON, Courtney. Trust and Mistrust in Americans' Views 
of Scientific Experts. Publicado em 02 de Agosto de 2019. Disponível em: https://www.pewresearch.org/science/2019/08/02/trust-and-mistrust-inamericans-views-of-scientific-experts/

17 SHAPIN, Steven. Weber's Science as a Vocation: A Moment in the History of 'Is' and 'Ought'. Journal of Classical Sociology, v. 19, p. 290-307, 2019.

18 TRACINSKI, Robert. Climategate: The Fix Is In. Publicado em 24 de novembro de 2009. Disponível em: https:/www.realclearpolitics.com/articles/2009/11/24/ the fix is in_99280.html.

19 SHAPIN, Steven. Invisible Science. The Hedgehog Review, v. 18, n. 3, p. 34-46, 2016.

20 SHAPIN, Steven. The Ivory Tower: The History of a Figure of Speech and Its Cultural Uses. British Journal for the History of Science, v. 45, p. 1-27, 2012.

21 Uma observação histórica: na época de Galileu e Newton, uma distinção crucial foi feita entre filosofia natural - considerada como uma investigação da natureza última das coisas e dos processos causais - que poderia ser interpretada como uma busca pela Verdade, e práticas matemáticas (por exemplo balística, estática, fortificação, observação astronômica) - que era somente a busca pelas regularidades, pelo poder preditivo, e as bases da ação prática: veja WESTMAN, Robert S. The Astronomer's Role in the Sixteenth Century: A Preliminary Study. History of Science, v. 18, p. 105-147, 1980; BIAGIOLI, Mario. The Social Status of Italian Mathematicians, 1450-1600. History of Science, v. 27, p. 41-95, 1989.

22 Veja: JOHNSON, Courtney. Most Americans are wary of industry-funded research. Publicado em: 04, Outubro de 2019. Disponível em: https://www. pewresearch.org/fact-tank/2019/10/04/most-americans-are-wary-of-industry-funded-research/

23 As duas crises são tratadas como se fossem as mesmas em: ROSENFELD, Sophia. Democracy and Truth: A Short History. Philadelphia: University of Pennsylvania Press, 2019; ROSENFELD, Sophia. Truth and Consequences. The Hedgehog Review, v. 21, no. 2, p. 18-24, 2019; BELL, Daniel A. An Equal Say: Where Does Truth Fit into Democracy? The Nation, v. 308, n. 4, p. 27-31, 2019.

24 FOUCAULT, Michel. Truth and Power. In: FOUCAULT, Michel. Power/Knowledge: Selected Interviews \& Other Writings 1972-1977. Ed. GORDON, Colin. New York: Pantheon, 1980. pp. 109-133, pp. 126-131 (citação completa na p. 131). 